\title{
Clinicopathological aspects and their relation to prognosis in adult-type granulosa cell tumor of the ovary
}

\author{
Aspectos clinicopatológicos e sua relação com o prognóstico em tumor de células da granulosa \\ do tipo adulto do ovário
}

Maurício De Angelo Andrade'; Joyce de Brito Pupo²; Sophie Derchain ${ }^{3}$; Liliana Aparecida Lucci De Angelo Andrade ${ }^{4}$

key words
Ovary
Ovarian neoplasias
Granulosa cell tumor
Prognosis
Clinical-pathologic study

Clinical-pathologic study

\section{abstract}

Introduction and objective: The adult granulosa cell tumors (AGCT) correspond to less than $5 \%$ of ovarian neoplasias. They are considered low malignant potential tumors and may recur after many years. The differential diagnosis must be made with other primary or metastatic ovarian neoplasias. The aim was to analyze clinical and pathological aspects of AGCT and relate them to its evolution. Method: in a 10year (1995-2004) review of the files from University of Campinas Clinical Hospital, Brazil, 20 AGCT cases were found. The clinical records and slides were reviewed and age, symptoms, macro and microscopic aspects, diagnostic staging and recurrence were considered. When there was intraoperative biopsy, its accuracy was evaluated. Results: Age ranged from 27 to 79 years (mean: 53) and the follow-up from 12 to 96 months (mean: 42). The main symptoms were post-menopause bleeding (45\%), abdominal pain (35\%) and palpable mass (25\%). Most tumors were yellowish (60\%) and the solid aspect (40\%) was more common than the cystic or solid-cystic. The histological patterns were $40 \%$ solid, $15 \%$ macrofollicular and $45 \%$ combined forms. All of them with low mitotic index. Only three out of nine intraoperative frozen sections were accurately diagnosed. The clinical staging was 13 cases in la (65\%), one case Ic and 6 lllc. In three out of 14 hysterectomies there was simple endometrial hyperplasia with no atypia. Only the disease staging was significantly associated with recurrence $(p<0.0001)$. Conclusion: ACGT generally occurs after menopause and intraoperative biopsies are commonly inconclusive. Only advanced staging was related to the worst prognosis.

\section{resumo}

Introdução e objetivo: 0 tumor de células da granulosa tipo adulto (TCGA) corresponde a menos de 5\% das neoplasias ovarianas. São de baixo potencial de malignidade, podem recorrer depois de muitos anos, e o diferencial deve ser feito com outras neoplasias primárias ou metastáticas. Analisamos os aspectos clínicos e patológicos do tumor, relacionando-os à evolução. Métodos: Na revisão de 10 anos dos arquivos do laboratório de Anatomia Patológica do Hospital das Clínicas da Universidade de Campinas (UNICAMP), 20 casos de TCGA foram encontrados. Os prontuários e as lâminas foram revisados e considerados: idade, sintomas, aspectos macro e microscópicos, estádio ao diagnóstico e à recidiva. Quando houve biópsia intraoperatória, sua acurácia foi avaliada. Resultados: A idade variou de 27 a 79 anos (média: 53); o seguimento de 12 a 96 meses (média: 42 ). Os sintomas principais: sangramento pós-menopausa (45\%), dor abdominal (35\%) e massa palpável (25\%). A maioria era amarelada (60\%), o aspecto sólido mais comum (40\%) que o cístico ou sólido-cístico. Os padrões histológicos foram: 40\% sólido, 15\% macrofolicular e 45\% de formas combinadas, todos com baixo índice mitótico. Apenas três de nove casos submetidos à biópsia intraoperatória foram diagnosticados corretamente. O estádio clínico foi: 13 casos la (65\%), um caso Ic e seis, IIlc. Em três de 14 histerectomias analisadas, havia hiperplasia endometrial simples sem atipia. Apenas o estádio da doença foi significativamente associado à recidiva $(\mathrm{p}<0,0001)$. Conclusão: TCGA geralmente ocorre após a menopausa, as biópsias intraoperatórias são mais comumente inconclusivas e apenas o estádio avançado esteve relacionado com o pior prognóstico. unitermos

Ovário

Neoplasia do ovário

Tumor de células da granulosa

Prognóstico

Clinicopatológico

1. Estudante do quinto ano da Faculdade de Ciências Médicas da Universidade de Campinas (UNICAMP).

2. Estudante do quinto ano da Faculdade de Ciências Médicas da UNICAMP.

3. Livre-docente; professora do Departamento de Tocoginecologia da Faculdade de Ciências Médicas da UNICAMP.

4. Doutora; professora titular do Departamento de Anatomia Patológica da Faculdade de Ciências Médicas da UNICAMP. 


\section{Introduction}

Ovarian sex cord-like tumors are uncommon, normally have a low grade biological behavior and represent around $6 \%$ of ovarian primary tumors ${ }^{(2)}$. According to WHO classification, there are several types of tumors classified as predominant cell type and granulosa cell tumor (GCT) is the most common among them, which corresponds around $70 \%(7,13)$. Although considered a low grade neoplasm, GCT is responsible for most death from sex cord-like tumors category. It is sub-classified according to the histological aspects in adult (more common) and juvenile GCT, which occurs generally before puberty, is very rare and its prognosis is excellent, with tumor recurrence or metastasis being uncommon. It corresponds to around 5\% of all $\mathrm{CCT}{ }^{(10)}$.

The adult type appears at reproductive age or postmenopause. Adult granulosa cell tumour (ACCT) is regarded as a low malignant potential neoplasm since there is a significant propensity for recurrence or metastasis ${ }^{(7)}$. AGCT is more related to estrogenic manifestations, clinically observed in $60 \%$ of cases. However they can be non-functional or occasionally virilizant $^{(9)}$.

Due to its low incidence and multiple histological aspects, AGCT represents a challenge for the histological diagnosis as well as for the evaluation of prognostic factors and its clinical behavior.

The aim of this paper is to describe twenty cases of AGCT, which took place during a ten year period, analyzing several clinical and pathological aspects, relating them to the evolution of the disease.

\section{Material and methods}

We searched the 1995 to 2004 archives of the University of Campinas Clinical Hospital Pathology Laboratory for the diagnosis of ACCT. The medical records were reviewed for disease-specific parameters such as: stage, tumor size, frozen section diagnosis, treatment modalities and follow-up. Histological slides were reviewed and the following aspects evaluated: a) growth pattern, b) mitotic index by ten high power field (hpf). Clinical and histological data were analyzed and related to recurrences. The significance was tested by Fisher and Mann-Whitney statistic tests. A probability value of 0.05 or less was considered statistically significant. The study was approved by the Research Ethics Committee of the institution.

\section{Results}

We found 20 AGCT. The age at diagnosis ranged from 17 to 79 years (median, 53 years). The most common symptoms were: postmenopausal bleeding (45\%), abdominal pain (35\%) and palpable abdominal mass (25\%). Most cases had ultrasonography with hypoechogenic images showing cystic or solid-cystic complex abdominal masses.

Tumor size: ranged from 3.5 to $25 \mathrm{~cm}$ (median, 12 $\mathrm{cm}$ ) and the tumor weight from 10 to 2,135 g. Most of them were yellow (60\%) and the internal surface was solid $(40 \%)$, cystic (30\%) or solid-cystic (30\%). In two cases there was a tumor rupture during the surgery (10\%).

Intra-operative frozen sections: were carried out in nine of the twenty cases (45\%) and the correct diagnosis of AGCT was performed only in tree cases (33\%). The other diagnoses were: cystadenoma (four cases: 44\%), undifferentiated carcinoma (one case: 11\%), and malignant neoplasia, pointing to wait for permanent sections (one case: $11 \%$ ).

The surgical proceedings were: 14 hysterectomies with bilateral oophorectomies and six simple unilateral oophorectomies.

Clinical stage: $65 \%$ were la (13/20 cases), $10 \%$ Ic (one case) and $30 \%$ Illc (six cases), advanced disease with abdominal implants. In Table 1 we grouped the tumors in two categories, according to the longest diameter. We did not find any correlation between tumor diameter and the recurrence of the disease (Table 2).

The follow-up period: ranged from 12 to 96 months (mean: 42 months) and there was only one death caused by the tumor.

Recurrence: six of the twenty cases showed recurrences (30\%), half of them occurring in the first year after the surgery. In one case, tree recurrences were observed: the first, a year later after the surgery; the second, four years; and the third, five years. The single patient who died, had two recurrences: tree and seven years after the first surgical proceeding. The majority of the recidives was observed at the Illc stage (five/six cases: $83 \%$ ) and only one patient was at the Ic disease stage (Table 1). Four cases showed recurrent tumors in the pelvis and in the other cases they were observed in the contralateral ovary, omentum or rectum. The patient with tree recurrences had pelvic, lung and liver metastasis. From the two ruptured tumors during the surgery, only one showed recidive. According 
to the statistical analysis only the stage of the disease was related to recurrences (Table 2: $p<0.0001$ ).

Histological aspects: AGCT presented many histological patterns: solid (40\%), macrofolicular (15\%) and mixed aspects (trabecular, insular, solid and microfolicular) in $45 \%$ of the cases (Figure). Mitotic index was generally low, ranging from one to eight mitotic figures (MF) by $10 \mathrm{hpf}$. However, in 17 cases, it was lower than five MF/10 hpf. No association was found between the number of mitosis, stage of the disease or recurrence (Tables 1 and 2). In tree cases, Sertoli cells were focally observed in the tumor and theca cells in another one. Atypia was rare, light and focal.

Associated endometrial lesions: hysterectomy was performed in 14 cases and the surgical specimens showed the following diagnosis: endometrial polyps (five cases), simple endometrial hyperplasia without atypia (tree cases), disordered proliferative endometrium (one case), hypotrophic endometrium (one case) and proliferative endometrium (four cases).

\section{Discussion}

Among several ovarian neoplasms, AGCT is not common and considered of low malignant potential. Because of its low occurrence, which represents less than $5 \%$ of all malignant ovarian tumors ${ }^{(9,13)}$, twenty cases are a representative sample and can supply information to increase knowledge of this disease.

Age: in spite of the wide age range of this sample's tumors, the average age of 53 is in accordance with the data in the literature which describes it as more common in postmenopausal and middle-aged women ${ }^{(7,9)}$.

Symptoms: Most patients showed postmenopausal uterine bleeding, that is related to the patient's age and it could point to the increasing of estrogen production by the tumor. However, many AGCT did not express any hormonal symptom; pain or abdominal mass are more common. The ultrasonographic aspects are not characteristics of any type of ovarian tumor and the
Table 1

\begin{tabular}{|c|c|c|c|c|c|}
\hline Diameter $(\mathrm{cm})$ & Gross & Histologic pattern & MI & Stage & Recurrence \\
\hline 6 & Ruptured cyst & Solid & 3 & IIIC & 3 \\
\hline 8 & Solid & Solid + trabecular & 2 & la & - \\
\hline 9 & Cystic & Macrofolicular & 1 & la & - \\
\hline 7.5 & Solid-cystic & Microfolicular + trabecular & 1 & la & - \\
\hline 3.5 & Cystic & Solid & 2 & IIIC & 2 \\
\hline 5.5 & Solid & Solid & 2 & la & - \\
\hline 4.5 & Solid-cystic & Solid + microfolicular & 3 & la & - \\
\hline 7.5 & Solid & Microfolicular + trabecular & 4 & la & - \\
\hline 8 & Solid & Insular + macrofolicular & 1 & la & - \\
\hline 5 & Solid-cystic & Solid & 2 & la & - \\
\hline 9 & Solid & Solid & 2 & Ic & 1 \\
\hline 13 & Solid-cystic & Solid & 5 & la & - \\
\hline 19 & Cystic & Trabecular + macrofolicular & 2 & la & - \\
\hline 20.5 & Solid & Macrofolicular & 2 & la & - \\
\hline 12 & Solid & Solid + trabecular & 3 & la & - \\
\hline 17 & Ruptured cyst & Microfolicular + solid & 2 & IIIC & - \\
\hline 25 & Solid & Solid & 6 & la & - \\
\hline 25 & Cystic & Macrofolicular & 1 & IIIC & 1 \\
\hline $\mathrm{N}$ & Cystic & Trabecular + macrofolicular & 8 & IIIC & 1 \\
\hline $\mathrm{N}$ & $\mathrm{N}$ & Solid & 3 & IIIC & 1 \\
\hline
\end{tabular}

Case description according to gross aspects, hystological patterns, stage of the disease and number of recurrences

N: without information; MI: mitotic index: mitotic figures/10 high power field. 
\begin{tabular}{|l|l}
\hline Table 2 & Recurrence of granulosa cell tumor and its relation to different aspects
\end{tabular}

Aspects of the tumor

Size*

(cm)

N

Mean

Std
No

14

12.32

8.55
Recurrence

$\%$

Yes

4

10.88

9.68

Gross

Without information

Ruptured

cyst

Cyst

1

Solid

Solid-cystic

6

4

7.1

21.4

42.9

21.6

0.7688

Histological pattern

Insular +

macrofolicular

Macrofolicular

Microfolicular + trabecular

solid

Solid +

microfolicular

Solid +

trabecular

Trabecular +

macrofolicular

1

2

2

4

2

7.1

14.3

14.3

28.6

14.3

14.3

7.1

0.2782

0.6758

p value

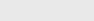

20

60

20

$\begin{array}{ll}1 & 0\end{array}$

1

Mitotic index*

14

2.57

1.5

Std

Stage of the disease

$\begin{array}{ll}\text { la } & 13 \\ \text { Ic } & 0 \\ \text { IIlc } & 1\end{array}$

13

Fisher test/ *Mann-Whitney test.

gold standard for the diagnosis is only the histological examination ${ }^{(7,12)}$.

Tumor size: ranged from 3.5 to $25 \mathrm{~cm}$ in diameter (Table 1), with solid, cystic or solid-cystic appearance, according to the literature $(3,4,7,9,10)$. Several studies have found tumor size to be of value in predicting recidive ${ }^{(7)}$. However, it is not always clear whether this factor is independent of tumor stage. In some studies, when stage was adjusted for, tumor size had no impact on survival( ${ }^{(7)}$. According to our cases, we conclude that there is no association between tumor size and recurrence.

The gross aspects are very important to contribute to the differential diagnosis with carcinoma. AGCT are softer, more 


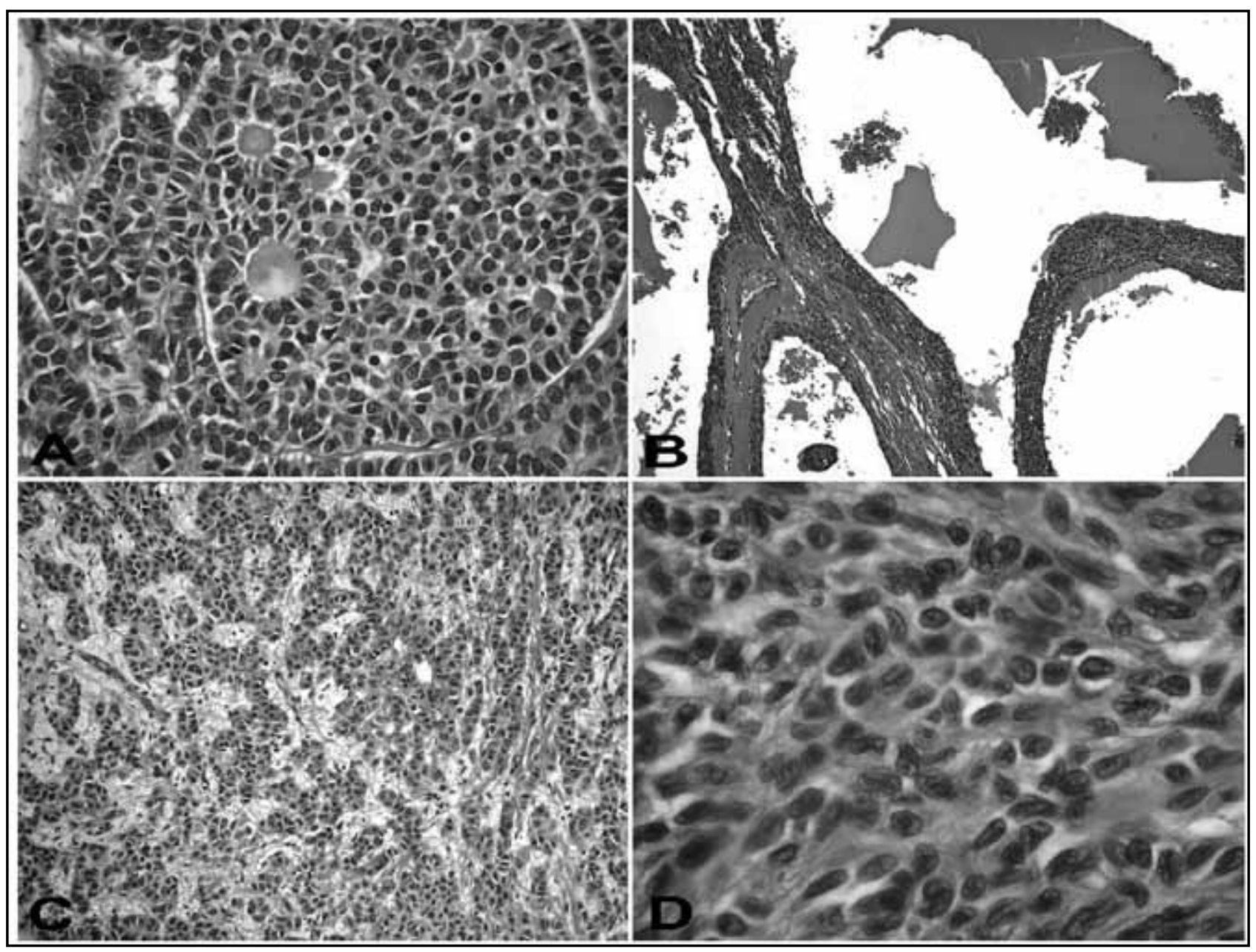

Figure - Granulosa cell tumor microscopic aspects: A: microfolicular pattern and Call-Exner bodies (HE X100); B: macrofolicular pattern (HE 40X); C: trabecular or cord-like pattern (HE 40X); D: solid, diffuse or sarcomatoid pattern (HE 200X)

yellowish than carcinomas and show common hemorrhagic cysts, responsible for tumor rupture, observed in $10 \%$ of our cases. Yellow color and the consistence softer than the adenocarcinomas are helpful in differential diagnosis $(3,8,10,12)$. This hemorrhagic aspect can also be confused with ectopic pregnancy in some cases ${ }^{(1,3,5)}$.

Differential diagnosis: AGCT has several morphological patterns and these aspects are very important for the differential diagnosis with many other primary or metastatic ovarian tumors. In general, AGCT is a difficult diagnosis in intra-operative examination as has been described in the literature ${ }^{(7-9)}$. In our sample, the diagnosis was correct in only one third of the cases submitted to frozen sections. Fortunately, most of the observed mistakes were associated with benign tumors. However, when AGCT has a solid pattern, the main differential diagnosis is undifferentiated carcinoma that suggests a more aggressive surgical procedure, unnecessary for AGCT. It is important to note that very often, the pathologist during the frozen examination does not know the patient's clinical data. But, he must always keep in mind the possibility of AGCT in the differential diagnosis, although, in many cases, only the permanent sections can provide the final diagnosis.

In doubtful cases, the procedure is to wait for the permanent sections for the final diagnosis and the best intraoperative decision must be ever more conservative in younger patients ${ }^{(12)}$. About $65 \%$ of our cases were in la stage, different from carcinomas that are often at advanced stage, according to other series $(1,3-5,8,11,12)$. However, intra-abdominal or distant metastasis in the liver or lungs can be observed in rare cases ${ }^{(4)}$, which was found in only one patient sample, which had recurrence in our series.

We did not find any association between tumor volume and stage of the disease. The poor evolution, with recidives was related to the stage of the disease at the diagnosis (Table 2), as related in the literature ${ }^{(7,1,3,5) \text {. }}$

However, this type of tumor has an indolent nature and needs a long follow-up ${ }^{(8)}$, because late recurrences can occur after 30 years ${ }^{(11)}$. In our series the median follow-up was 42 
months and recidives took place in only six cases $(6 / 20,30 \%)$, which indicates these patients need a life-time follow up ${ }^{(11)}$.

Fourteen out of the 20 cases were submitted to hysterectomy and simple endometrial hyperplasia without atypia was found in tree specimens (21\%). Endometrial carcinoma was not found, although there are reports of this association in $5 \%$ to $10 \%$ of $\operatorname{AGCT}^{(3,5,10)}$.

There are several AGCT microscopic patterns and the classic Call-Exner bodies are related to the microfolicular or welldifferentiated type. Very often, AGCT is not well-differentiated, showing cordonal, insular, solid or sarcomatoid aspects (Figure). According to the literature, the different microscopic patterns do not predict the prognosis and it is common to find mixed aspects in the same tumor ${ }^{(12)}$, as observed in our cases.

The monotonous and vesicular nuclei, a prominent longitudinal nuclear groove and the low mitotic index are helpful in differential diagnosis with carcinoma ${ }^{(9)}$. AGCT rarely contains bizarre nuclei, a feature that does not alter the prognosis but can lead to misdiagnosis as a more malignant neoplasm ${ }^{(9)}$.

In some reports, the nuclear grade and mitotic index are linked to poor prognosis ${ }^{(4,12)}$, although it must be emphasized that when there are high grade nuclear atypia and a high mitotic index (more than $5 \mathrm{MF} / 10 \mathrm{hpf}$ ) the AGCT diagnosis could be doubtful and the differential diagnosis should be

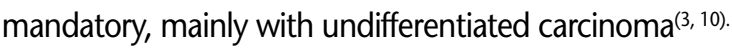

Immunohistochemical positive reactions with alphainhibin, calretinin, vimentin and CD99 expresions are helpful for the AGCT diagnosis ${ }^{(3,8)}$.

In our series, only one case had $8 \mathrm{MF} / 10 \mathrm{hpf}$ in the mitotic index. This patient was Illc stage and presented abdominal recurrence during the first year after surgery. So, we cannot declare that this poor evolution was related to the mitotic index because she was already at an advanced stage of the disease at diagnosis.

In this 20-case study, we can conclude and point out some important aspects: a) the low frequency of AGCT contributes to difficulties in the diagnosis as well as in the treatment; $b$ ) in most cases, the ACCT was not a suspected preoperative diagnosis and only the histological examination can confirm it; c) the intraoperative frozen section diagnosis is generally difficult in AGCT; d) the tumor volume, the diverse histological patterns and the mitotic index were not related to the prognosis; $\mathrm{e}$ ) only the stage of the disease was related to the poor evolution with recurrences.

\section{References}

1. AURANEN, A. et al. Prognostic factors of ovarian granulosa cell tumor: a study of 35 patients and review of the literature. Int J Gynecol Cancer, v. 17, p. 1011-8, 2007.

2. BROOKS, S. E.; ZWEIZIG, S. L.; WAKELEY, K. Ovarian cancer: a clinician's perspective. Pathology Case Reviews, v. 11, n. 1, p. 3-8, 2006.

3. FOX, H.; AGRAWAL, K.; LANGLEY, F. A. A clinicopathologic study of 92 cases of granulosa cell tumor of the ovary with special reference to the factors influencing prognosis. Cancer, v. 35: p. 231-41, 1975.

4. FUJIMOTO, T. et al. Histopathological prognostic factors of adult granulosa cell tumors of the ovary. Acta Obstet Gynecol Scand, v. 80, p. 1069-74, 2001.

5. KIM, Y. M. et al. Adult granulosa cell tumor of the ovary: 35 cases in a single Korean Institute. Acta Obstet Gynecol Scand, v. 85, p. 112-5, 2006.

6. MCCLUGGAGE, W. G. Immunohistochemical and functional biomarkers of value in Female Genital Tract Lesions. Int J Gynecol Pathol, v. 25, p. 101-20, 2006.

7. MILLER, K.; MCCLUGGAGE, W. G. Prognostic factors in ovarian adult granulose cell tumor. J Clin Pathol, v. 61, n. 8 , p. $881-4,2008$.
8. PINTO, P. B. C; ANDRADE L. A. L. A.; DERCHAIN, S. F. M. Accuracy of intraoperative frozen section diagnosis of ovarian tumors. Gynecol Oncology, v. 81, 230-2, 2001.

9. ROTH, L. M. Recent advances in the pathology and classification of ovarian sex cord-stromal tumors. Int J Gynecol Pathol, v. 25, p. 199-215, 2006.

10. SCULLY, R. E.; YOUNG, R. H.; CLEMENT, P. B. Tumors of the ovary, maldeveloped gonads, Fallopian tube and Broad Ligament: Atlas of Tumor Pathology. Fascicle 23, Washington, DC: AFIP, 1998.

11. SINGH-RANGER, G.; SHARP, A.; CRINNION, J. N. Recurrence of granulosa cell tumor after thirty years with small bowel obstruction. Int Semin Surg Oncol, v. 1, n. 1, p. 4, 2004.

12. STUART, G. C. E.; DAWSON, L. M. Update on granulosa cell tumors of the ovary. Curr Opinion Obstet Gynecol, v. 15, p. 33-7, 2003.

13. TAVASSOLI, F. A.; DEVILLE, P. Tumors of the breast and female genital organs. In: TAVASSOLI, F. A.; DEVILLE, P. (eds.). World Health Organization Classification of Tumors. Lyon: IARC Press; 2003. 